\title{
Research on the Game Analysis of Central and Local Governments under the Perspective of Intergovernmental Relations
}

\author{
Li ZHENG \\ School of Management, Wuhan Textile University, Wuhan, 430070, China \\ email: 641690546@qq.com
}

Key words: the central government; local governments; interest game; decentralization reform

\begin{abstract}
Structurally, China is a unitary centralized state in which all the power institutionally belongs to the central government while local governments at various levels are executive agencies of the central government and should faithfully perform and implement the central government's policies. But in fact, the local governments also are the groups of interest's distribution and have relatively independent interest requirements, resulting in a deviation trend between central and local governments gradually. This paper emphasizes on discussing the current situation and plight of political and economic game between the central and local governments, furthermore the corresponding solutions are proposed.
\end{abstract}

\section{Introduction}

In our daily life, we feel more power of local governments. The central government still exists, but for society, it is difficult to feel its power. It seems that in decision-making related to government, we see the figure of the local government more often. China's current political ecology still belongs to political authority. [1] The government holds the right allocation of the vast majority of resources, but the power of the central government is hard to reach local governments. Since ancient times China has had one parlance of “the imperial power doesn't reach county". [2] Under such a background it is easy to lead to egoism of local governments, namely the use of local resources for their own profits. Currently, if the central government lacks determination and proper strategies to solve the political symptoms, it could result in further solidifying the condition of local power elite's challenging central authority and the worst type of political authority, namely the" Sudan Regime” as professor Xiao Gongquan said. [3] Specifically, such power refers that the local authorities rarely are influenced by administrative practices and traditions and can use power at will. They use their accumulated interpersonal relationship network and carry out cronyism, forming a huge vested interest group with a large number of resources, and to a certain extent have enough capitals to confront with the central government.

\section{Current Relationship between the Central and Local Governments}

The central and local governments gradually present the trend of deviation, which is determined by China's existing authoritative political system. Compared with the system before the reform and opening up, the existing system is not integrity of individual and country any longer, and the administrative power doesn't be involved in every corner of society. Combined with the reality, however, it is still a "late universal politics". [4] To be specific, the government no longer manages everything, but in the power contrasts between the state and society, the country is in overwhelming superiority. It governs the life of people by laws, rules, documents and instructions, and more often, the local government is the main body of formulating and implementing these specifications.

One feature of the late universal politics is the low political participation of citizens. It is hard for citizens to restrict the government's decision, even if the decision is closely related to people's own interests, such as the violent law-enforcement phenomenon in the process of housing demolition. People lack institutional constraints on the power of the government while the government maintains strong control of civil society to ensure that their authority avoids the 
challenge from the public. [5] And under the" late universal” authoritative system, the central government lacks adequate and effective channels to understand local information and the local governments blockade news against their own interests, so it's difficult for the central government to know the abnormal information of local governments, which reinforces the Sudan trend of local authority and the event of Jiangsu iron provides excellent footnote.

From the perspective of the political structure, China is a unitary centralized state where the central government is the highest power center and local governments in theory are the executive agencies and extension of the central government and should faithfully perform and implement the central government's policies. But the reality is that local governments have become prospective interest groups, owning relatively independent political and economic interests and managing society according to the will of themselves and local actual situations. If the central policy cannot satisfy the interests of the local governments, they almost all execute it passively or take resistance, leading to difficult implement of the central government's will in place.

Since the early 80s the decentralization reform is the initial source of the trend. The original intention of the central government was to stimulate the initiative of the local economic development. The expected effect of the reform at that time must be admitted, but its negative influence over time also emerged: making the local government intensify the tendency of localism and produce the central centrifugal impulses. Local people feel more presence of local government, and to the central government, just keep an abstract fuzzy understanding. In other words, after the retreat of central power system, the local governments in actually became communes and the central government lost the ability of going deep into regions.

Starting from the reality, we can come to the conclusion that although the local officials in China's modernization process have an indelible contribution, however, we cannot ignore its negative inside. On the one hand, under the convenience provided by the low political participation system, local officials can avoid the powerful political challenges outside system. Due to the constraint of system, society cannot appear the power which can challenge and restrain bureaucrats that have solid interest, which is so easy to form exclusive monopolistic local bureaucrats that are "too big too fail". The local governments also have capitals to play game with the central government. Many central decrees such as protecting the interests of the farmers, banning arbitary charge and cutting cadres cannot be implemented, which has a great relationship to local officials who adopt negative resistance in order to maintain their own interests. On the other hand, it is a characteristic of "late universal system" that Chinese society naturally lacks internal organization strength, and China lacks the system of easing and decreasing tensions by the endogenous mechanism of civil society and autonomous society especially compared with Latin America and East Asia. So we can believe that after entering the intermediate stage of China's reform, local officials’ benefits under authority system have already solidified exclusively.

\section{Reasons and Measures of the Game Plight between the Central and Local Governments}

Firstly, it is the result of immature system. The central government lacks close contact with grassroots and their supports, in other words, the central government's current power is not established based on the immediate contact with people. People have more abstract ideas and unspeakable sense of distance about the central government, but strong perception to local governments.

Of course, this does not mean that the central government has completely lost control of the local governments and the main way of central government's control of local control is personnel system, such as cadres appointment and dismiss, transfer, local officials into Beijing, and the central sent officials to local office. But the problem is that in addition to the personnel system, there is no other way for the central government to control local governments, and single channel inevitably leads to the lack of control. On such a basis, the central government has formed excessive dependence on this path which is the plight of relations between the central and local governments and the root cause of conflicts between both. The effectiveness of relying on the personnel system control only is questionable. Over the past 20 years, local governments set a series of policies and 
rules and its purpose is to promote the local economic development. Due to the natural self-interest of government, these policies and rules formed the institutionalization of local government interests. Local government sets policies from local interests while the central sets policy starting from the interests of the whole country, however, the two can't be completely overlapped at any time, thus the contradiction appears. And the problem is that if there is no local policy and regulation, realizing the control of the central government to the whole nation is impossible.

The central government implements central policies and realizes central will through appointing local officials. But local interests do not change any or disappear. This requires that the central government have sufficient political wisdom and strategic thinking, dealing with the local relationship with new ideas. When conflicts of interests between the central government and local government appear, the current common solution is that the former use their own advantages to suppress local interests. But it is not a wise thing totally, even if there is short effects, there is no benefits in the long run. The more acceptable measure is recognizing the local interests, meanwhile, strengthening the direct link with the grassroots, thereby increasing its authority, strengthening its legitimacy and increasing weight in the game with the local government.

To do this, the ideal way is to increase the direct election and reduce indirect elections. But there is no realistic condition to do this. Imagine, administrative leaders at all levels of government are elected by the people, which must result in strong impact on" stable", the most concerned question by the party in power. If this is the case, people's political enthusiasm which has been repressed for a long time will surely erupt like a volcano, a process that there will be a lot of uncontrollable factors which will result in the sharp impact on the regime. Constitutional reform of late Qing dynasty was ended in failure because the businessmen-based public political participation was booming. However, the Qing court's political system was unable to absorb the participation of emerging social strata, and lacked the coherence ability of controlling people, thus facing serious dilemma. If people were allowed to continue the development of political participation, the Qing court would collapse in the participation of surge wave; If political participation movement was repressed, the court would lose the social basis of constitutional reform. Because the Qing court couldn't control people's political enthusiasm and adopted the method of clamping down which led to people's thorough frustration to government and the democratic revolution in the late Qing dynasty, and the Qing court also died in the people's revolution.

The present Chinese government only allowed on the local level, different forms of election. The Chinese and foreign observers generally believed that China currently adopts a bottom-up democratization road. As any coin has two sides, the democratization from bottom to top has two sides. Its advantage is being gradual and stable, which does not cause widespread political unrest, and that's what the high-level of ruling party extremely pays attention to. But its disadvantages also cannot be ignored: firstly, when the legitimacy moves down, people will have higher recognition to local government, which sharpens local tendency and impulse of resisting the central government. Secondly, the region will enable to emphasize local special interests, so national integration will be more difficult.

Secondly, China's reform has an obvious characteristic that is it's from easy to difficult and political system reform lags behind economic reform for a long time. Reform and opening up starting in the $1980 \mathrm{~s}$, has been cleverly avoided a series of problems and contradictions. As a result, nearly 30-yearreform and opening up although greatly liberated the productive forces and led to rapid economic growth, at the same time also has made many contradictions be concealed by the surface of the good economic situation. Reform consciously avoided the most sensitive and core problems of the old system. From the point of view of system reform, the rapid growth did not promote structural adjustment and change. In the transformation period, the reform projects which were considered to be difficult, such as the state-owned enterprises reform, financial system reform and local selfish departmentalism now are still difficult tasks. More and more people have realized that, under the condition of high growth, the reform is not getting easier, but more change more difficult. The miracle of high-speed economic development throughout the history of the world, there are few more than 30 years. China's rapid economic increase has lasted for many years, and 
how long this state last is still in the air. Therefore, the central government must have a consideration on the system innovation and make the reform of China take the track of healthy development. Since the decentralized movement in the $80 \mathrm{~s}$, local power has been more and more prominent, but the central government's control of local governments presents decline signs. Local governments compared to the central government have more foundation of people and legality. If this phenomenon develops at will, the result need to be considered seriously by the leader level.

In China, local governments often are combination with" soft power" and strengthen each other. Therefore, the central authority must be firstly strengthened. In the historical condition where market mechanism and contractual social ties development are not yet mature, the country should maintain the mechanism of sufficient authoritative legitimacy resources and use the resources to strengthen instruction implement which is the basic way to overcome the local government self-interest; Next, we need to deepen market economy reform and use the normative power gradually of market to replace the original pure social economic and political regulation derived from authoritative political function; Then, our country need to foster civil society and build an orderly broad political participation mechanism, preventing any local government above the country and society.

\section{Conclusion}

As a behind external deriving modernized nation, political change is the "bottleneck" factor that restricts the course of modernization of other areas, and the realization of political transformation is related the achievement of goals of the whole modernization. But the first condition of political modernization is to set up effective centralized power. As a typical exogenous modernization country, China today is in a profound social change, and a lot of contradictions in social change can find root cause in the political realm. If politics reform is not carried out, society will be stagnant. Its reason is political reform's lagging behind economic reform, and tremendously inert political and highly active economy are not compatible. At the same time, the relationship between the central and local government is also the difficulty of the reform. If we cannot go out of current plight, reform will inevitably lose motivation and direction. Political development is a process in which political system loses stability and obtains it again. The fundamental secret of maintaining and establishing political stability is to adapt to changing internal and external environment, and how to achieve this goal has no fixed answer, needless to say the only answer. Somebody thinks that going on reform means to break the stability of political system, but the author thinks dynamic stable view should be taken in the problem. The essence of a dynamic stability is continuously breaking the current situation and replacing the old balance with new balance. Political reform could damage the current situation, but that does not be equal to social unrest. On the contrary, well-designed and mature reform is more likely to mean the arrival of a new state of equilibrium. Political exploring space is open, and any stereotypes of prediction or simple choice is conservative.

\section{References}

[1] Jiang Rushan. No Stagnancy and Mistakes in Reform [M]. Hongkong International Business Newsletter. 2015. 1.

[2] Kang Xiaoguang. On Corporatism State[M]. Strategy and Management. 2013. 3.

[3] Tao Dan. Chinese Reform Becomes Harder and Harder[M]. Hongkong International Business Newsletter. 2015.4.17.

[4] Wang Shaoguang, Hu Ankang. Strategy of The Second Reform: Promoting the Building of National Systems[M].Strategy and Management. 2014. 1.

[5] Bai Liu. Cultural Policy in the People’s Republic of China. Journal of Women s Health . 1983 